\title{
A Skeptical Attitude About Product Liability is Justified: A Reply to Professors Goldberg and Zipursky
}

\section{Citation}

A. Mitchell Polinsky \& Steven M. Shavell, A Skeptical Attitude About Product Liability is Justified: A Reply to Professors Goldberg and Zipursky, 123 Harv. L. Rev. 1949 (2010).

\section{Published Version}

http://www.harvardlawreview.org/media/pdf/vol123_polinsky_shavell.pdf

\section{Permanent link}

http://nrs.harvard.edu/urn-3:HUL.InstRepos:10900866

\section{Terms of Use}

This article was downloaded from Harvard University's DASH repository, and is made available under the terms and conditions applicable to Open Access Policy Articles, as set forth at http:// nrs.harvard.edu/urn-3:HUL.InstRepos:dash.current.terms-of-use\#OAP

\section{Share Your Story}

The Harvard community has made this article openly available.

Please share how this access benefits you. Submit a story.

Accessibility 


\title{
A SKEPTICAL ATTITUDE ABOUT PRODUCT LIABILITY IS JUSTIFIED: A REPLY TO PROFESSORS GOLDBERG AND ZIPURSKY
}

\author{
A. Mitchell Polinsky* and Steven Shavell**
}

In The Uneasy Case for Product Liability, ${ }^{1}$ we maintained that the benefits of product liability are likely to be less than its costs for many products, especially widely sold ones. Our article was intended to alter the dominant view held by the judiciary and commentators that product liability has a clear justification on grounds of public policy. We argued instead that a skeptical attitude toward product liability should be adopted.

Professors John Goldberg and Benjamin Zipursky strongly criticize our article in The Easy Case for Products Liability Law: A Response to Professors Polinsky and Shavell. ${ }^{2}$ To a significant extent, however, they attack a straw man, for they impute to us a radical thesis - that product liability should be eliminated for all widely sold products ${ }^{3}-$ that we manifestly did not advance. In fact, we argued that whether

* A. Mitchell Polinsky is the Josephine Scott Crocker Professor of Law and Economics at Stanford Law School. Polinsky's research on this reply was supported by the John M. Olin Program in Law and Economics at Stanford Law School.

** Steven Shavell is the Samuel R. Rosenthal Professor of Law and Economics at Harvard Law School. Shavell's research was supported by the John M. Olin Center for Law, Economics, and Business at Harvard Law School.

Both authors are also Research Associates of the National Bureau of Economic Research. The authors received helpful comments on this reply from Tom Baker, Scott Hemphill, Louis Kaplow, and David Rosenberg, and gratefully acknowledge research assistance from Eric Hansford, Jeffrey Kessler, and Rakesh Kilaru.

1 A. Mitchell Polinsky \& Steven Shavell, The Uneasy Case for Product Liability, I2 3 HARV. L. REV. I437 (2010).

2 John C.P. Goldberg \& Benjamin C. Zipursky, The Easy Case for Products Liability Law: A Response to Professors Polinsky and Shavell, I23 HARV. L. REV. I9I9 (2010).

3 They say, for example, that "the burden of Uneasy is to defend the . . ambitious claim that products liability law ... is unjustified - that is that any and all tort liability for injuries caused to consumers by widely sold products should be eliminated." Id. at I925-26. Likewise, they state that "Uneasy ... generates the striking conclusion that a consumer injured by a widely sold product should not recover in tort from the manufacturer." $I d$. at 1927 . In their discussion of the reform of law, they refer at one point to our recommendation as "the elimination of liability for injuries to consumers caused by widely sold products," $i d$. at I94I, and at another point as "an abandonment of tort law for widely used consumer products," $i d$. at 1942. Sometimes they describe our recommendation in a slightly less radical way. For instance, in their introduction they represent our claim to be "that it is probably desirable for manufacturers not to be subject to any tort liability for injuries caused to consumers by widely sold products." Id. at I92 I (emphasis in original). While this version of their statement of our position is softened by the word "probably," it nonetheless mischaracterizes our position because we do not say in our article that there is any possibility that product liability should be eliminated for all widely sold products. 
product liability is undesirable depends on the particular product. ${ }^{4}$ Goldberg and Zipursky also ascribe to us other opinions that exaggerate what we said in our article - notably, they state that we believe that product liability has no beneficial effect on product safety for widely sold products. ${ }^{5}$ It is not surprising, therefore, that they are unable to support these mischaracterizations with citations to statements in our article. ${ }^{6}$

The major claim that Goldberg and Zipursky develop is that our benefit-cost analysis fails to demonstrate that the case for product liability is uneasy. ${ }^{7}$ In our view, their critique is deficient on multiple accounts, including that it contains numerous distortions and errors, and hence does not alter our original conclusion.

4 In the abstract of our article we said that the use of product liability will be "often unwarranted," not always unwarranted, on account of a consideration of the benefits and costs of product liability. Polinsky \& Shavell, supra note I, at I438. In the second paragraph of our Introduction, we similarly said that the benefits of product liability are likely to be outweighed by their costs "for many products," but not for all products. Id. at I440. In the beginning of Part VI, which summarized and concluded our benefit-cost analysis, we said that "[w]e are focusing here on central tendencies" and that, "as the reader knows, the assessment of benefits and costs will not be uniform within each category of products [widely sold products and products that are not widely sold]." Id. at 1472 .

5 See infra pp. 1956-57.

6 With only one exception, the assertions quoted from their response in supra note 3 are not accompanied by footnotes with citations to our article. Moreover, the single exception, a footnote intended to support the italicized quotation in supra note 3, does not make sense. In that footnote, Goldberg and Zipursky correctly quote us as saying that, in light of our analysis, legislation might be contemplated "that would limit or eliminate product liability in certain industries or for certain widely sold products." Goldberg \& Zipursky, supra note 2, at I92 I n.I 7 (quoting Polinsky \& Shavell, supra note I, at I492). But our statement that mentions the possibility of eliminating product liability in certain industries or for certain widely sold products obviously does not support their claim that we contemplate eliminating product liability for all widely sold products.

7 See id. at I922. They also advance other arguments for product liability, notably that it is warranted by a relevant notion of justice, independently of its standard public policy benefits. Id. at $1944-48$. In their view, justice is promoted if a manufacturer that introduces a product into the stream of commerce is held responsible for injuries caused by its defects. Id. at 1943-44. Although we limit our discussion in the text of this reply to the conventional benefits and costs of product liability, we observe here that Goldberg and Zipursky ignore three important issues bearing on the applicability of the justice rationale for product liability to which they refer. One issue is whether firms' employees or firms themselves should be viewed as moral actors. Compare Peter A. French, The Corporation as a Moral Person, in Collective Responsibility I33 (Larry May \& Stacey Hoffman eds., I99I) (maintaining that corporations can be held morally accountable for their acts), with Manuel G. Velasquez, Why Corporations Are Not Morally Responsible for Anything They Do, in COLLECTIVE RESPONSIBILITY, supra, at I I (arguing that only employees can be morally responsible for their acts). If employees are the sole moral actors, justice would require that culpable employees be penalized, not the firm as an entity. The second issue of relevance to the justice rationale for product liability is the extent to which firms' ownership of liability insurance dilutes the achievement of justice, because insured firms do not directly pay for the harms they cause. See, e.g., Louis Kaplow \& Steven Shavell, Fairness Versus WELFARE II4-I5 (2002). And the third issue is the degree to which first-party insurance interferes with the achievement of justice, because subrogation often results in insurers rather than plaintiffs receiving tort payments. See $i d$. 
We begin in Part I by considering the safety benefit of product liability, namely, that it spurs firms to reduce product risks. A central point of our article was that this benefit is incremental in character. It consists only of the steps that product liability induces firms to take to reduce accident risks beyond those that they already take in response to market forces (to avoid losses in sales if their products injure customers) and to comply with safety regulation. We argued in our article that market forces and regulation often contribute in a significant way to product safety, particularly for widely sold products, and thus that the safety benefit of product liability might not be great.

Goldberg and Zipursky do not dispute our basic observation that the safety benefit of product liability is incremental in nature; they do not deny that market forces and regulation are often important determinants of product safety. What they do contend, however, is that the magnitude of the safety benefit of product liability is large, notwithstanding that it is incremental. We explain why the various arguments that they present to support this view are problematic. In doing so, we address their criticisms of our discussion of several empirical studies involving general aviation aircraft, motor vehicles, and childhood vaccines - that fail to find that product liability has a measurable effect on product safety. We observe that their evaluation of these studies is incomplete, reflects questionable judgments about the interpretation of empirical work, and contains errors. Significantly, Goldberg and Zipursky do not cite any study demonstrating that product liability has led to a decrease in product accident rates. ${ }^{8}$ In the end, we see no reason to modify our conclusion that the safety benefit of product liability is incremental and that it is often small, especially for widely sold products for which market forces and regulation are strong.

In Part II we examine the second major benefit of product liability - that it compensates victims of product-related accidents for their harms. As we stressed in our article, the compensation benefit also is incremental, because victims of product-related accidents already often receive substantial compensation from private and public insurance. Moreover, due to subrogation provisions in insurance contracts, as well as other factors, the product liability system adds much less to victims' compensation than the amounts that firms pay in settlements or judgments. Again, Goldberg and Zipursky do not dispute our basic points. However, they argue that the magnitude of the compensation benefit is

\footnotetext{
8 They do, however, make the false claim that such empirical studies are discussed in Daniel P. Kessler \& Daniel L. Rubinfeld, Empirical Study of the Civil Justice System, in I HANDBOOK OF LAw And Economics 343, 363 (A. Mitchell Polinsky \& Steven Shavell eds., 2007). See Goldberg \& Zipursky, supra note 2, at I93I-32. But Kessler and Rubinfeld do not mention any empirical studies that show that product liability has led to a decrease in product accident rates. See infra notes 32-37.
} 
large, even though it is incremental; and they criticize our analysis of the detrimental effects of awarding damages for pain and suffering. We explain why we find their assertions unconvincing or incorrect.

In Part III we discuss the comparison of the benefits of product liability to its costs. ${ }^{9}$ We noted in our article that the legal costs of the product liability system are large - they approximate the amount that victims receive in compensation. We observed that employing the product liability system to compensate victims is like using an ATM that imposes a service charge of \$100 for every $\$$ Ioo a person withdraws from it. We also discussed indirect costs of product liability stemming from the price increases it induces, which can undesirably discourage consumers from buying products. The high costs of product liability, combined with the points that the safety and compensation benefits are incremental and often small, led us to the judgment that product liability may well be undesirable for many products.

Despite the obvious importance of the costs of the product liability system, Goldberg and Zipursky do not discuss them. Nonetheless, they press the assertion that the case for product liability is easy to make. It is surprising that Goldberg and Zipursky should do this because, of course, it is illogical to conclude that the case for product liability is easy to make without taking into account its costs - unless they believe that the costs of product liability are irrelevant to its evaluation.

A theme of Goldberg and Zipursky's response is that we must meet a heavy burden of persuasion to justify our skeptical attitude toward product liability. We believe, however, that the burden on us is weak. In a major part of our article, not commented upon by Goldberg and Zipursky, we documented the conclusory nature of the policy arguments for product liability offered by courts and most commentators. That essentially no serious policy rationale for product liability has been provided by them implies that the burden on us to challenge the status quo is not great. It should not be difficult to cast doubt on a policy position that has no real basis - that is not supported by a developed body of arguments and facts. We believe that the analysis that we offered and the evidence that we presented amply support our conclusion that the case for product liability is uneasy.

\footnotetext{
9 In our article we also considered the price-signaling benefit of product liability - that product liability can improve consumer purchase decisions by causing product prices to increase to reflect product risks. See Polinsky \& Shavell, supra note I, at I459-62. Because Goldberg and Zipursky do not address this benefit other than to summarize it in a footnote, see Goldberg \& Zipursky, supra note 2, at I926 n.32, we do not discuss it here.
} 


\section{The Safety Benefit of PRoduct Liability}

The main point that we developed in our article concerning the safety benefit of product liability is, as we noted above, that it is of an incremental nature because safety improvements will often already be stimulated by market forces or required by regulation. We amplified this point through a qualitative discussion of ways in which market forces and regulation work to generate safety, as well as through a review of empirical studies of the effect of product liability on product safety. Goldberg and Zipursky criticize our analysis on three grounds. The first concerns whether the present level of regulation should be taken as given in assessing the contribution of product liability to safety. The second relates to our qualitative discussion of market forces and regulation. The third involves our assessment of empirical studies of product liability. As we explain, their various arguments are problematic or incorrect.

\section{A. Should We Have Taken the}

\section{Present Level of Regulation as Given?}

In assessing the contribution of product liability to product safety, we took other factors that affect product safety as given. We said that "we consider the desirability of product liability against the background of the world as we find it, including the way in which market forces and regulation now operate." 10 This assumption was natural to make - in evaluating a particular policy, it is standard to take other policies as given - and we specifically noted that a more complicated inquiry was beyond the scope of our article. ${ }^{11}$

Nevertheless, Goldberg and Zipursky fault us for not having asked how much product liability would enhance product safety if regulation were nonexistent, and they imply that product liability would then contribute more to safety than it does now because it would not be incremental. ${ }^{12}$ It is undoubtedly true that product liability would add more to product safety if there were no regulation. However, as we suggested in our article, if one wanted to determine how much product liability would encourage product safety were regulation different from that today, a more appropriate investigation would involve

10 Polinsky \& Shavell, supra note I, at I443 n.I2.

11 See id.

12 They write:

[E]ven if one were to grant that tort law offers no incremental deterrent effect, this concession provides no grounds for the ultimate conclusion of Uneasy. Rather it provides an argument against redundant incentivizing. This is just as much an argument for dismantling the regulatory regime governing product safety as it is an argument for getting rid of tort law....

Goldberg \& Zipursky, supra note 2, at I93 I. 
consideration of improved or optimal regulation as a benchmark, not no regulation. ${ }^{13}$

Furthermore, if regulation could be modified in a desirable way, it is not clear that regulation would be less strong than it is currently. One might believe that regulation should be strengthened to offset its reduced effectiveness due to imperfections of the political process, including the capture of regulatory agencies. Thus, were we to evaluate the role of product liability relative to a different and better regulatory regime, it is plausible that product liability would have a less important role in promoting product safety than we found in our article. ${ }^{14}$

\section{B. Our Qualitative Discussion of the Safety Benefit of Product Liability}

In our discussion of the effect of market forces on product safety, we cited numerous examples in which consumer demand for a product declined dramatically after consumers learned of its dangers, as well as examples in which demand for a product rose as a consequence of consumer beliefs about its desirable safety characteristics. ${ }^{15}$ Goldberg and Zipursky dismiss these examples as anecdotes ${ }^{16}$ but do not question their validity.

We also catalogued ways in which consumers can obtain information about product risks through newspapers, magazines, the broadcast media, and the internet. ${ }^{17}$ We acknowledged that consumers' ability to absorb this volume of information is limited and that their evaluation of it is subject to cognitive problems. ${ }^{18}$ Goldberg and Zipursky do not disagree with our description of the product safety information available to consumers, but say that we should have paid greater at-

\footnotetext{
13 See Polinsky \& Shavell, supra note I, at I443 n.I2.

14 Similarly, if we evaluated the proper scope of product liability when consumer access to information about product risks is desirably modified, we might also discover that product liability would be less valuable than we judged it to be in our article. Probably at modest expense, the government could create enhanced public websites with up-to-date tracking of product problems for most widely sold products and for many others. In fact, the government is proceeding to establish a website of this sort. See U.S. Consumer Prod. Safety Comm'n, SaferProducts.gov, http://www.saferproducts.gov (last visited May 7, 20I0) (describing a "publicly accessible, searchable database of consumer product incident reports" that is intended to be operational by March II, 20II, id. at http://www.saferproducts.gov/timeline.html). In a world in which information about product risks is easier to obtain, firms would face stronger market penalties for selling dangerous products and would obtain greater rewards for making safer products. Thus, the likely contribution of product liability to product safety would be diminished.

15 See Polinsky \& Shavell, supra note I, at I $443-45$.

16 See Goldberg \& Zipursky, supra note 2, at I922 ("The evidence [Uneasy] marshals is surprisingly scant, consisting of anecdotes about products that suffered declining sales after being linked to certain injuries ....”).

17 See Polinsky \& Shavell, supra note I, at I $445-48$.

18 See id. at I448-49.
} 
tention to the difficulties that consumers face in making use of it. ${ }^{19}$ Additionally, we emphasized that consumers are likely to have better information about the safety of widely sold goods because the media tends to give these goods more attention than goods that are not widely sold. ${ }^{20}$ Goldberg and Zipursky do not criticize this hypothesis.

We then described several significant areas of safety regulation pertaining to automobiles, pharmaceuticals, aircraft, and consumer products - and observed that some safety regulations have been found to have reduced product risks. ${ }^{21}$ We noted as well that regulation is likely to be more effective with respect to widely sold products than other products because regulators will be more concerned with widely sold products and will be better able to obtain information about their risks.22 Goldberg and Zipursky do not dispute these points. Rather, they say that we placed too little weight on the problems afflicting regulation, ${ }^{23}$ even though we acknowledged that regulators face various difficulties (due to limited information, budgetary constraints, and capture by industry) and that regulation may not be successful. ${ }^{24}$

Goldberg and Zipursky also mention that product liability litigation can promote safety indirectly, by focusing the attention of consumers and regulators on product dangers. ${ }^{25}$ We recognized this informational role of product liability in our article. ${ }^{26}$ However, one might question its significance for widely sold products because problems with such products are more likely to be discovered even in the

19 See Goldberg \& Zipursky, supra note 2, at I 929.

20 See Polinsky \& Shavell, supra note I, at I449.

21 See id. at 1452.

22 See id.

23 See Goldberg \& Zipursky, supra note 2, at I930.

24 See Polinsky \& Shavell, supra note I, at I453. Specifically, we said:

Of course, regulation will be far from perfect due to the limited knowledge of regulators, their budgetary constraints, and the possibility that they may be captured by the firms that they are responsible for overseeing. Consistent with these observations, some studies have found regulation to be ineffective or of limited value in certain contexts.

Id. (footnote omitted). Notwithstanding this statement, Goldberg and Zipursky assert that:

The reader [of Uneasy] is left with the false impression that, on balance,... the Food and Drug Administration (FDA) and the National Highway Traffic Safety Administration (NHTSA) operate free from political influence, budgetary constraints, dependency on regulated entities for information, and the inherent limitations of ex ante regulation.

Goldberg \& Zipursky, supra note 2, at I930.

25 See id. at I930-3I.

26 See Polinsky \& Shavell, supra note I, at I454-55, where we said: Another reason that product liability could be effective is indirect - that product liability litigation may result in publicity about product problems and thereby enhance market forces and spur regulation. If adverse reactions to a drug would not come to the attention of the media or regulators unless product liability suits were brought, then product liability could be responsible for lower sales of the drug and regulatory action to remedy its dangers. 
absence of litigation, due to their pervasive use. Moreover, the empirical studies that we discussed in our article, and revisit in section I.C below, suggest that the informational role of product liability litigation is not important. Specifically, if such litigation had a substantial impact on product safety through the dissemination of information to consumers and regulators about product risks, the studies should have found that greater product liability activity is associated with lower accident rates; but this relationship is not evident in the studies' findings.

To summarize, Goldberg and Zipursky do not challenge our qualitative points that market forces and regulation already often provide considerable safety benefits - implying that the safety benefit of product liability is much less than would otherwise be supposed. Instead, they criticize us for not placing enough weight on limitations to our arguments, even though we discussed the very limitations that they emphasize.

\section{Empirical Studies of the Effect of Product Liability on Product Safety}

We considered in our article all of the empirical literature that we could locate that sought to identify the effect of product liability on product accident rates, and we focused attention on studies that were concerned with specific products. These products were general aviation aircraft, motor vehicles, and childhood vaccines. ${ }^{27}$ In none of the studies did researchers find that increased product liability litigation resulted in a measurable decrease in accident rates. ${ }^{28}$ The researchers failed to uncover a beneficial effect of product liability on product safety even though product liability litigation increased greatly during the periods studied (spanning the I970s and I980s).

Goldberg and Zipursky criticize our discussion of these studies on several accounts. In this section, we explain that their observations about this literature, and about what we said regarding it, contain errors, misleading statements, and questionable judgments concerning the interpretation of statistical results.

To begin, Goldberg and Zipursky misstate what we concluded from the empirical studies. They assert that we make the "improbable claim that widely sold products would be as safe if ... tort liability to

\footnotetext{
27 See id. at $1455-58$.

28 See id. (citing Andrew Craig, Product Liability and Safety in General Aviation, in THE Liability MAZE 456 (Peter W. Huber \& Robert E. Litan eds., I99I); John D. Graham, Product Liability and Motor Vehicle Safety, in The Liability MAZE, supra, at I20; Robert Martin, General Aviation Manufacturing: An Industry Under Siege, in The LiABILITy MAZE, supra, at 478; Richard L. Manning, Changing Rules in Tort Law and the Market for Childhood Vaccines, 37 J.L. \& ECON. 247 (I994)).
} 
consumers for product-related injuries were abolished." 29 We did not make such a claim. ${ }^{30}$ Our conclusions from the empirical studies were carefully qualified. In essence, we said that the studies suggested that the effect of product liability on product safety would likely be small in industries similar to those studied, but that the effect might be greater for the average widely sold product. ${ }^{31}$

Goldberg and Zipursky also incorrectly describe other scholars' reviews of empirical studies of the effect of product liability on product safety. They state that "two prior literature reviews - one published by Professor Mark Geistfeld in 2009, the other by Professors Daniel Kessler and Daniel Rubinfeld in 2007 - have already addressed the same empirical studies" that we do. ${ }^{32}$ However, neither of these reviews considers the studies of all three of the products that we discussed. Geistfeld mentions only automobiles, ${ }^{33}$ and Kessler and Rubinfeld discuss only general aviation aircraft. ${ }^{34}$ Goldberg and Zipursky also claim that Kessler and Rubinfeld point out that some studies have found that product liability leads to an improvement in product safety, yet this claim too is untrue. ${ }^{35}$ Additionally, Goldberg

29 Goldberg \& Zipursky, supra note 2, at I934.

30 The passage just quoted from Goldberg and Zipursky's response is not accompanied by a supporting citation to our article. In an earlier part of their response they similarly suggest that we believe that "tort law as applied to products does nothing at all to induce manufacturers to make safer products." Id. at I928 (emphasis in original). They do provide a footnote there referencing our article that is intended to support their claim: "See [Uneasy] at 22 (speculating that products liability produces only a 'small' safety benefit for widely sold products)." Id. at I928 n.35. Aside from the fact that this footnote does not accurately represent our position, it obviously contradicts their assertion that we believe that product liability "does nothing at all" to improve product safety.

31 Specifically, we stated that the findings of these industry studies "support the prediction that the safety benefit of product liability for many other widely sold products — those for which market forces and regulation have similar importance - will be small," but that "market forces and regulation may be more significant for general aviation aircraft, automobiles, and childhood vaccines than for the average widely sold product, implying that the safety benefit of product liability may be lower for these industries than more generally." Polinsky \& Shavell, supra note I, at I 458 .

32 Goldberg \& Zipursky, supra note 2, at I93 I (footnotes omitted).

33 See Mark A. Geistfeld, Products Liability, in TORT LAW AND ECONOMICS § II.II, at 302-03 (Michael Faure ed., 2d ed. 2009) (discussing the study by Professor John Graham of the effect of product liability on automobile accident rates). While Geistfeld also mentions two studies by Richard Manning on product liability and childhood vaccines, it is only to note Manning's findings about the impact of liability on vaccine prices, not on accident rates. Id. at 304 .

34 Kessler and Rubinfeld, supra note 8, at $36_{3}$, address the study by Robert Martin of the effect of product liability on general aviation accident rates, supra note 28; they do not discuss the Andrew Craig study of general aviation aircraft, supra note 28 , the Graham study of automobiles, supra note 28, or the Manning study of childhood vaccines, supra note 28.

35 Goldberg and Zipursky say that Kessler and Rubinfeld, supra note 8, at 363, report that "some studies have found a deterrent effect" of product liability. Goldberg \& Zipursky, supra note 2, at I93 I n.57. But on that page of Kessler and Rubinfeld's article (containing the relevant discussion of deterrence), the only studies of the deterrent effect of product liability on accident rates 
and Zipursky describe the authors of the surveys as being agnostic about the effect of product liability, and they imply that we misinterpreted the authors as concluding that product liability does not affect product safety. ${ }^{36}$ Goldberg and Zipursky do not mention, however, that we observed that Geistfeld and Kessler and Rubinfeld criticize the empirical studies that they review. ${ }^{37}$ We believe that a careful reader will find that we did not misinterpret these authors.

As to the studies of the three products themselves, Goldberg and Zipursky discuss only Professor John Graham's analysis of automobile safety. Graham investigated whether the increase in automobilerelated product liability litigation between $\mathrm{I} 950$ and $\mathrm{I} 988$ led to a reduction in the automobile accident fatality rate, and he did not find any statistically discernible effect. ${ }^{38}$ Not only do Goldberg and Zipursky neglect to report Graham's statistical result, they actually imply that he came to a contrary conclusion. ${ }^{39}$

Nonetheless, Goldberg and Zipursky complain that Graham's measure of liability activity was less than ideal and that his indicator of the accident rate was the fatality rate rather than a more compre-

that are mentioned are those by Professor George Priest and Robert Martin. Kessler and Rubinfeld state that Priest "concludes that the expansion of product liability had minimal (if any) beneficial effects on accident avoidance." Kessler \& Rubinfeld, supra note 8, at 363 . They say that Martin "finds sharper declines in the aviation accident rate from I950-69 than from I970-89," id., which is the opposite of what would be expected if the expansion of product liability in the latter period reduced accident rates.

36 See Goldberg \& Zipursky, supra note 2, at I93 г.

37 See Polinsky \& Shavell, supra note I, at I458 n.90. In a similar vein, Goldberg and Zipursky claim that Professors Don Dewees, David Duff, and Michael Trebilcock are agnostic about the effect of product liability on product safety and they imply that we overlooked this point. See Goldberg \& Zipursky, supra note 2, at I 933 (discussing DON DeweEs, DAVID DUfF \& Michael Trebilcock, Exploring the Domain of ACCident LaW (ig96)). But Goldberg and Zipursky do not acknowledge that we observed that Dewees, Duff, and Trebilcock criticize the study by Priest that they review. See Polinsky \& Shavell, supra note I, at I 455 n.66, I 458 n.90. Moreover, Goldberg and Zipursky do not mention that Dewees, Duff, and Trebilcock state, in the topical sentence of the paragraph from which Goldberg and Zipursky draw quotations supporting their claim that Dewees, Duff, and Trebilcock are agnostic, the following: "Aggregated empirical analysis ... suggests that increased product liability has not led to any decrease in product-related accidents." DEWEES, DUFF \& TREBILCOCK, supra, at 205.

38 Graham, supra note 28 , actually observed that greater product liability activity was associated with a higher accident rate, but the effect was not statistically significant. See id. at I8283. See also infra note 46 and accompanying text.

39 They say the following:

In an effort to refine these gestalt judgments [based on particular automobile safety events], the Graham article also looks for a statistical correlation between increases in the incidence of so-called "crashworthiness" liability for automobile-accident injuries and reductions in such injuries. By this method, it finds that products liability law "is one of several forces that induce manufacturers to consider making pro-safety decisions in the marketplace," and that "[i]n some cases... liability seemed to cause safety improvements to occur more quickly than they would have occurred in the absence of liability."

Goldberg \& Zipursky, supra note 2, at I928 (emphasis added) (footnotes omitted). 
hensive accident rate. ${ }^{40}$ But the use of imperfect measures of variables when better alternatives are not available is commonplace in empirical work. Moreover, because the rates of fatal and nonfatal accidents are obviously strongly correlated, it is unlikely that the rate of nonfatal accidents decreased, or decreased by very much, when the rate of fatal accidents did not decline.

In addition to his statistical analysis, Graham undertook five detailed case studies of automobile safety problems (including, for example, gas tanks in Ford Pintos that were prone to explode in accidents). ${ }^{41}$ In doing so, he attempted to identify in a qualitative way the contribution made by product liability to automobile safety. Goldberg and Zipursky describe Graham's conclusions from these case studies as indicating that product liability was often a contributing factor to the adoption of safety improvements ${ }^{42}$ and may have hastened some improvements. ${ }^{43}$ That is a correct reporting of what Graham said, as we too stated, ${ }^{44}$ but it is seriously incomplete.

In particular, Graham made three other significant observations that cast product liability in a far less favorable light and that Goldberg and Zipursky do not mention. First, Graham stated that "[i]n no case did we conclude that liability considerations were necessary to stimulate a specific safety improvement." 45 Second, Graham said that, although "liability is sometimes a contributing pro-safety factor" in the case studies, a statistical analysis of "passenger car occupant fatalities for the years I950 to I988" indicates that "any beneficial impact of liability is too small and subtle to be detected." 46 Third, when Graham offered recommendations for the improvement of automobile safety, he

40 See id. at 1928 n.39.

41 Graham's five case studies account for the bulk of his long article — fifty-five of its sixtyseven pages of text. His study of Ford Pinto gas tank problems is approximately ten pages in length. Yet Goldberg and Zipursky describe Graham as "briefly recounting episodes such as the Ford Pinto gas-tank ruptures." Id. at 1928.

42 See id. Goldberg and Zipursky write that Graham's study "speculates for each [safety improvement] whether products liability law 'was a necessary, sufficient, contributing, or insignificant cause of safety improvements,' concluding that in most instances 'liability was a contributing factor in achieving safety improvements." Id. (footnote omitted) (quoting Graham, supra note 28 , at $\mathrm{I} 80-8 \mathrm{I})$.

43 See id. Goldberg and Zipursky quote the following passage from the Graham article: "[i]n some cases... liability seemed to cause safety improvements to occur more quickly than they would have occurred in the absence of liability." Id. (alterations in original) (quoting Graham, supra note 28 , at $183-84$ ).

44 See Polinsky \& Shavell, supra note I, at I457 \& n.83. We observed that Graham "noted ... that product liability might have been sufficient to induce certain safety improvements or at least to have hastened them, especially because the adverse publicity accompanying litigation can spur market forces." Id. at 1457 (footnote omitted).

45 Graham, supra note 28 , at I 80 .

$46 I d$. at $182-83$. The reference in the text is to the statistical study by Graham that we described above. See pp. I958-59. 
identified two strategies that he described as "particularly promising," namely, "provision of better safety information to consumers and a revitalized federal regulatory process." ${ }^{47} \mathrm{He}$ did not suggest expanding the use of product liability. ${ }^{48}$

It is thus evident that Graham's overall judgment is that product liability has played a minor role in promoting automobile safety and that he does not advocate its greater use. The impression of Graham's views conveyed by Goldberg and Zipursky is based on highly selective citations to his article and is, in our opinion, inexcusably misleading.

Goldberg and Zipursky also criticize us for placing too much weight on studies of general aviation aircraft and childhood vaccines because, they say, these are atypical products. ${ }^{49}$ They appear to believe that aircraft are atypical because, in their view, there is little that manufacturers can do to improve aircraft safety. ${ }^{50}$ But it is obvious that there are many ways in which aircraft manufacturers can make their planes safer, for instance by improving their structural integrity, adding backup features to their critical components (such as their landing gear), and designing them to be more resistant to stalling and spinning. Airplanes are not qualitatively different from the multitude of complicated manufactured products for which all manner of steps can be taken to improve safety.

Thus, results from an empirical study of the effect of product liability on general aviation aircraft safety should be able to teach us something about the effect of liability on the safety of other products. Suppose, for example, that we were considering gas cooking ranges that, like general aviation aircraft, had to conform to rigorous safety requirements and were purchased by consumers who well appreciated their risks. Then we might reasonably predict from the results regard-

\footnotetext{
47 Graham, supra note 28 , at 185.

48 Graham recommended two reforms of product liability. One was to reduce the scope of product liability by giving firms a defense against liability when they "promptly correct design defects and practice safety innovation." $I d$. at 186 . The other was to forbid confidentiality of product liability settlements in order to increase consumer information about product problems.

49 See Goldberg \& Zipursky, supra note 2, at 1932.

50 Goldberg and Zipursky say that "planes are unusual in that there is a complete overlap between the technology that is required for them to perform at all and the technology that is needed to prevent the occurrence of the most significant hazard that they pose." Id. They follow this statement with a sentence that makes it clear that the significant hazard to which they are referring is crashing. See id. What Goldberg and Zipursky thus seem to mean is that if a plane is made such that it "perform[s] at all," it will be made such that it will not crash. If their statement does not have this interpretation, and their view is instead that safety can vary among airplanes that "perform at all" - that is, that the probability that planes will crash can vary - then their view is the one we articulate in the text, and their claim that airplanes are atypical would be contradicted.
} $I d$. 
ing general aviation aircraft that product liability would also have little effect on the safety of the gas cooking ranges.

Similarly, Goldberg and Zipursky apparently believe that childhood vaccines are atypical because there is not much that manufacturers can do to make them safer. ${ }^{51}$ But the safety of a vaccine can be improved through changes in its design (for instance, by employing an inactivated virus instead of an attenuated one), through the exercise of care in its manufacture (such as by preventing its contamination), and through the provision of warnings about its use. Because vaccine manufacturers can affect product safety, something can be learned about the influence of product liability on product safety from the empirical study of vaccines.

Goldberg and Zipursky claim as well that we were selective in the empirical studies that we mentioned. ${ }^{52}$ Yet the only sense in which we were selective was that we focused on studies that examined the effect of product liability on actual accident rates. We said that we were excluding surveys that asked company officials what steps they undertook to improve product safety as a result of product liability, because such surveys do not measure the impact of liability on accident rates..$^{53}$ Moreover, surveys of this type are often of questionable reliability. For example, two surveys undertaken by the U.S. Conference Board in consecutive years in the I 980 os to evaluate the effect of product liability on firm behavior have been described as coming to markedly different results. ${ }^{54}$

Finally, Goldberg and Zipursky stress that the empirical studies that we cite examine only the influence of the adoption of modern product liability law - that is, only the effect of "the shift from a negligence standard to a defect-based standard." ${ }_{55}$ Hence, they suggest, it is possible that modern product liability law does not generate a safety benefit even though the prior law applicable to product accidents, which they describe as based on negligence, may have had a substan-

\footnotetext{
51 See id. at 1932-33 (stating that "the number of alternative design options available to manufacturers is limited by human biology, scientific knowledge, and FDA regulations" and that "manufacturers ... have limited ability to respond to the liability signal").

52 See id. at 1932.

53 See Polinsky \& Shavell, supra note I, at I 458 n.89. In any case, were we to have considered surveys of this sort, it is doubtful that they would have affected our conclusions. See infra note 54.

54 See Dewees, DufF \& TREBILCOCK, supra note 37, at I97-98 (discussing two national surveys undertaken by the U.S Conference Board in I 986 and I987 "to evaluate the impact of product liability on firm behavior" and noting that "[t]he results of [the second] survey contrast markedly with those of the first"). Dewees, Duff, and Trebilcock conclude their review of these surveys by observing that, while "the effect of tort law has not been insignificant, ... [b]oth the presence of 'adverse' and 'beneficial' effects and the absence of cost-benefit evaluations preclude a conclusion as to whether increased product liability has enhanced efficient deterrence." Id.

55 Goldberg \& Zipursky, supra note 2, at I 933.
} 
tial beneficial effect on safety. ${ }^{56}$ This conjecture is implausible. Suppose that under the negligence standard firms were induced, as Goldberg and Zipursky hypothesize, to exercise various risk-reducing precautions in order to avoid being found liable for negligence. Then, under the more expansive defect-based standard, firms should also have been induced to take various additional risk-reducing precautions in order to avoid being found liable for product defects. If firms had done this, there would have been a reduction in product accident rates; yet the results of the empirical studies that we reviewed failed to find any effect of product liability on accident rates, contradicting the hypothesis of Goldberg and Zipursky. ${ }^{57}$

\section{The Compensation Benefit of Product Liability}

We emphasized in our article that the compensation benefit of product liability is also incremental in nature. Most individuals are already compensated to some, if not a substantial degree, for productrelated losses by first-party insurers. We additionally explained that awards for pain and suffering lower individuals' well-being because these awards effectively force individuals to purchase a type of insurance that most do not want. Goldberg and Zipursky criticize our analysis on both accounts in ways that we find unconvincing or mistaken.

\section{A. The Incremental Nature of the Compensation Benefit}

In support of our point that individuals receive significant compensation for product-related accidents from insurance, we observed that most Americans have private or public insurance coverage for medical expenses, loss of life, disability, and property damage. We noted that about $85 \%$ of the population possesses health insurance, approximately

\footnotetext{
56 See id.

57 We elaborate here on the logic behind the argument just described. Suppose that there are two important safety precautions, call them $\mathrm{P}_{\mathrm{I}}$ and $\mathrm{P}_{2}$, which are cost-justified and which, ideally, would be undertaken by firms to reduce the risk of product defects. But suppose that only $\mathrm{P}_{\mathrm{I}}$ is required under the negligence standard either because courts are not cognizant of the desirability of $\mathrm{P}_{2}$ (for example, a court might not know that the rate at which soft drink bottles are cooled after being manufactured affects the likelihood of their later cracking and causing injury) or because courts cannot verify whether $\mathrm{P}_{2}$ was undertaken (a court might not be able to obtain reliable evidence on the cooling rate). Then, under Goldberg and Zipursky's hypothesis that the negligence standard generates a substantial safety benefit, firms would be led to undertake $\mathrm{P}_{\mathrm{I}}$ under the negligence standard but would not be led to undertake $\mathrm{P}_{2}$. However, if it is rational for firms to exercise precaution $P_{I}$ under the negligence standard, it will also be rational for them to exercise $\mathrm{P}_{2}$ under the more expansive standard that holds them strictly liable for defect-caused injury. Hence, an empirical finding that firms did not take precaution $\mathrm{P}_{2}$ under the defect-based standard is inconsistent with their taking precaution $\mathrm{P}_{\mathrm{I}}$ under the negligence standard. The empirical studies that we reviewed effectively show that $\mathrm{P}_{2}$ was not taken.
} 
$78 \%$ of families own life insurance, at least one-third of the workforce holds some form of disability coverage, and $96 \%$ of homeowners have property insurance. ${ }^{58}$ Goldberg and Zipursky do not dispute these statistics, but they fault us for not discussing how many individuals have insufficient insurance relative to their losses. ${ }^{59}$ We did not claim, however, that insurance coverage was generally so high that there would be no compensation benefit from product liability. We acknowledged in our article that "a significant minority [of Americans] lack coverage, and the level of coverage of those who have insurance may be substantially less than their losses." 60

Nonetheless, the level of coverage of individuals who have insurance will often be adequate to compensate them for the majority of their losses. For example, aside from deductibles and copayments, private health insurance reimburses individuals for most of their medical costs, ${ }^{61}$ and homeowner's insurance typically covers the cost of repairing or rebuilding a home that is damaged or destroyed by fire or other perils. ${ }^{62}$ More generally, because the losses that individuals suffer in accidents lie along a continuum, most losses will not be extreme; our conjecture is that they will typically be less than the ceilings on individuals' insurance policies. ${ }^{63}$ In other words, in the majority of cases, insurance will be sufficient to cover losses after deductibles and copayments. However, a qualification to this statement applies in the case of disability coverage, which is usually limited to approximately $60 \%$ of an individual's income. ${ }^{64}$

We also observed in our article that individuals do not obtain as much compensation through the product liability system as might first appear. $^{65}$ One reason is that subrogation provisions in first-party insurance policies often result in insurers collecting the settlements or judgments paid by defendants. Another reason is that legal fees and delays in payment reduce the amount and the value of the compensa-

\footnotetext{
58 Polinsky \& Shavell, supra note I, at $\mathrm{I} 462$.

59 See Goldberg \& Zipursky, supra note 2, at 1935.

60 Polinsky \& Shavell, supra note I, at I463.

61 See Chris L. Peterson, Cong. Research Serv., Setting and Valuing Health INSURANCE BENEFITS 4 (2009), available at http://assets.opencrs.com/rpts/R4049I_200904 o6.pdf.

62 See Insurance Information Institute, What Is in a Standard Homeowners Insurance Policy?, available at http://www.iii.org/Articles/What-is-in-a-standard-homeowners-insurance-policy .html (last visited May 7, 2010).

63 The theory of insurance suggests that risk-averse individuals would buy insurance policies that protect them against most losses, especially large ones. See generally Kenneth J. ARrow, ESSAYS IN THE THEORY OF RISK-BEARING I34-43 (I97I).

64 See Lawrence B. Keller \& Harry R. Wigler, Disability Insurance Planning for Professionals, CPA J., Dec. 2007, at 54, 56 ("Most insurance companies will issue disability insurance coverage equal to approximately $60 \%$ of earned income.").

65 See Polinsky \& Shavell, supra note I, at I463-65.
} 
tion that plaintiffs receive. Goldberg and Zipursky do not disagree with these points.

We then considered the value to individuals of the compensation that they obtain as a result of the product liability system. ${ }^{66} \mathrm{We}$ emphasized that the value of each dollar of compensation obtained through product liability tends to be less than the value of each dollar of compensation received through insurance. The explanation is that insurance payments are typically received first and thus are presumably used to satisfy a victim's most pressing financial needs after an accident.

Although Goldberg and Zipursky seem to accept this point in theory, they question its significance in practice. ${ }^{67}$ They state that the force of our claim "hinges on the actual slope of plaintiffs' utility curves,"68 but do not acknowledge that we considered such curves. Specifically, we gauged the importance of our point using economists' estimates of individuals' utility curves, and calculated in an example that the value of a dollar received from the product liability system is only half of that received from insurance. ${ }^{69}$ Goldberg and Zipursky offer no evidence to counter what we illustrated.

In sum, Goldberg and Zipursky do not contest our central point that the compensation benefit of product liability is limited because substantial compensation is already furnished by first-party insurers. They also do not dispute our observation that subrogation, legal fees, and delays detract from the compensation provided by product liability. Instead, they emphasize the incompleteness of insurance coverage, but do not provide evidence about the seriousness of this matter. Finally, they question the significance of our claim that the value of product liability dollars received by injured parties is lower than that of insurance dollars, but they do not offer meaningful support for this criticism.

\section{B. Nonmonetary Awards and the Compensation Benefit}

We explained in our article that product liability detrimentally affects individuals to the extent that it compensates them for nonmone-

\footnotetext{
66 See id. at I466-67.

67 See Goldberg \& Zipursky, supra note 2, at 1937-38.

$68 I d$. at I937. They also imply that the importance of our argument would be reduced if an individual received a small amount of compensation from insurance and a large amount of compensation from the product liability system. We see no reason why this would be so. Imagine, for example, that an individual receives only a dollar of compensation from insurance and the remainder of the compensation for her loss from product liability. Then the dollar of compensation from insurance would have higher marginal utility - possibly much higher because it is the first dollar received - than the average marginal utility of the subsequent dollars received as a result of product liability.

69 See Polinsky \& Shavell, supra note I, at I466-67.
} 
tary losses, notably for pain and suffering. ${ }^{70}$ We said that such compensation tends to have relatively low value to individuals "because pain and suffering per se usually do not increase one's need for money." 11 The benefit of this compensation is more than offset by the increase in product prices that results from firms' having to pay pain and suffering damages. Awarding such damages, we observed, is akin to forcing individuals to purchase insurance for nonmonetary losses, a type of insurance that they generally do not desire.

Goldberg and Zipursky do not appear to disagree with this point in principle, but they doubt its import. They begin by making a confused assertion. They mistakenly say that we claim that "the consumer will be made worse off in an amount equal to the entire extra cost of the product attributable to the manufacturer's having to stand ready to pay for pain and suffering damages." 72 In the illustration that we employed, to which they refer, the price of a product rose by $\$$ I 000 because the manufacturer has to pay pain and suffering damages in the event of an accident. ${ }^{73}$ But contrary to the claim of Goldberg and Zipursky, we did not say that the consumer was made worse off by the price increase, here $\$ 1000$. Rather, we calculated that the loss in welfare of the consumer in our example was $\$ 365.84 .{ }^{74}$

Goldberg and Zipursky also suggest that our criticism of awards for nonmonetary losses is usually inapplicable in practice. They argue that, even though the law allows awards for nonmonetary damages, this does not normally result in accident victims actually receiving more than their monetary losses. The reason that Goldberg and $\mathrm{Zi}$ pursky give is that victims typically are compensated through settlements rather than trial awards, and the settlement amounts are usually less than victims' monetary losses. ${ }^{75}$ To illustrate their point, suppose that a victim's monetary loss is $\$ 100,000$, that she settles for $\$ 60,000$, and that half of this settlement amount is attributable to her being able to claim damages for pain and suffering. Then the $\$ 30,000$ portion of the settlement due to pain and suffering damages helps to com-

70 See id. at 1467-69. As we observed there, this point is well known in the economics literature. See id. at I 468 n.I25.

71 Id. at 1467.

72 Goldberg \& Zipursky, supra note 2, at 1939.

73 See Polinsky \& Shavell, supra note I, at I 468

74 Id. at I468 \& n.I 24. Goldberg and Zipursky also say: "That the consumer would decline to spend $\$ 365.84$ for pain and suffering insurance does not establish that she would pay nothing for it; rather it means that she would only pay some lower amount." Goldberg \& Zipursky, supra note 2, at $1939 \mathrm{n} .86$. This statement is wrong because its premise is incorrect. It is not true that the consumer would decline to spend $\$ 365.84$ for pain and suffering insurance. In fact, she would be willing to spend more than $\$ 365.84$ for such insurance (it can be inferred from our example that she valued the insurance at $\$ 634$.I 6 because the product price rose by $\$ 1000$ and she suffered a welfare loss of only $\$ 365.84$ ).

75 See id. at $1939-40$. 
pensate her for her monetary loss of $\$ 100,000$; the right to receive pain and suffering damages at trial can thus function to augment her compensation for her monetary loss. Consequently, according to Goldberg and Zipursky, the award of pain and suffering damages usually is beneficial, not detrimental. ${ }^{76}$

Although we agree with Goldberg and Zipursky that the award of damages for nonmonetary losses can lead, through the settlement process, to fuller compensation for monetary losses, we believe that this point is unlikely to be of great significance. A victim will usually have some insurance, as we observed above, ${ }^{77}$ that will frequently compensate her for her monetary losses, apart from deductibles and copayments. In this event, the victim's receipt of the insurance payment will largely negate Goldberg and Zipursky's point because there will be little need for further compensation for monetary losses. Even if there is a shortfall in insurance coverage, the amount of the settlement attributable to the claim for monetary losses will often cover the shortfall. ${ }^{78}$

Additionally, the prospect of a nonmonetary award at trial may add enough to a settlement to overcompensate the victim for her monetary losses, and thus can reduce consumer well-being for the reasons that we provided in our article. This possibility seems significant to us because pain and suffering damages are comparable in magnitude to monetary damages. ${ }^{79}$

\section{The Benefit-Cost Evaluation of Product liability}

Having addressed Goldberg and Zipursky's observations about the benefits of product liability, we now turn to consideration of the costs of product liability and the comparison of benefits to costs.

We described in our article a number of studies that documented the high legal costs of tort liability. These costs are approximately equal in magnitude to the payments that tort victims receive in com-

\footnotetext{
76 See id. at 1940.

77 See supra pp. 1962-63.

78 Settlement proceeds are usually added to the victim's insurance payment when that payment does not fully compensate her for monetary loss. See Polinsky \& Shavell, supra note I, at I464 n. IO8 (citing KeNNETH S. ABRAHAM, INSURANCE LAW AND REgUlation 405-07 (4th ed. 2005); Alan O. Sykes, Subrogation and Insolvency, 30 J. LEGAL STUD. 383, 385 (2001)); see also Tom Baker, Blood Money, New Money, and the Moral Economy of Tort Law in Action, 35 LAW \& SOC'Y REV. 275, 30I-I3 (200I). Thus, to illustrate the possibility mentioned in the text, suppose that insurance covers $\$ 80,000$ of a $\$ 100,000$ monetary loss, so there is a $\$ 20,000$ shortfall in compensation. Then if the victim receives a settlement that includes (net of any legal fees) a $\$ 20,000$ component due to her claim for monetary loss, she would be able to fill the gap in compensation on account of that claim alone.

79 See Polinsky \& Shavell, supra note I, at 1462 \& n.98.
} 
pensation from defendants. ${ }^{80}$ We also discussed indirect costs stemming from product price increases due to product liability. These price increases can undesirably discourage consumers from buying products. $^{81}$ For example, the higher price of the DPT vaccine attributed to product liability litigation has been estimated to have led to more than a million children going unvaccinated. ${ }^{82}$ We noted as well that manufacturers might withdraw socially valuable products from the marketplace as a result of their bearing the costs of litigation and of pain and suffering awards, and we suggested that this happened with general aviation aircraft. ${ }^{83}$

Surprisingly, Goldberg and Zipursky ignore our entire discussion of the costs of the product liability system. ${ }^{84}$ But without comparing the benefits of product liability to its costs, one cannot assert, as they do, that the case for product liability is easy, unless one believes that costs do not matter. ${ }^{85}$ Obviously, if the product liability system were free to employ, the case for product liability would be immediate when product liability has positive benefits. But because the costs of the product liability system are so significant, they cannot be elided in a proper evaluation of product liability.

Goldberg and Zipursky also assert that we face a heavy burden of proof in arguing that a skeptical attitude toward product liability is warranted on the basis of our benefit-cost analysis. ${ }^{86}$ The burden on us would indeed be substantial if the policy rationale for product liability put forth by its proponents were a serious one, the result of sustained consideration of the benefits and costs of product liability.

But we demonstrated in a major part of our article that the policy basis for product liability that courts and commentators have offered is essentially conclusory. ${ }^{87}$ Goldberg and Zipursky make no reference to our discussion of this matter. We established that courts and commen-

\footnotetext{
80 See id. at $1469-70$.

81 See id. at $1470-72$.

82 Id. at 1474 (citing Richard L. Manning, Is the Insurance Aspect of Producer Liability Valued by Consumers? Liability Changes and Childhood Vaccine Consumption, I3 J. RISK \& UNCERTAINTY 37,47 (I996)).

83 See id. at $1475-76$.

84 They make only two passing references to the costs of the liability system. See Goldberg \& Zipursky, supra note 2, at 1922 (noting that product liability law "is expensive and in some ways unpredictable"); $i d$. at 25 (referring to "the expenses associated with the delivery of compensation via the tort system"). Oddly, however, they devote an entire part of their response to a discussion of the costs of changing from one set of legal policies to another. See id. at I94I-42 (Part IV titled "The Costs of Law Reform").

85 As we observed in the preceding footnote, Goldberg and Zipursky do care about the costs of law reform. We presume, therefore, that they would agree that the costs of the product liability system should be recognized as well.

86 See Goldberg \& Zipursky, supra note 2, at I935 (referring to the "heavy burden of persuasion set by Uneasy's central thesis").

87 See Polinsky \& Shavell, supra note I, at $\mathrm{I} 476-85$.
} 
tators simply presume that product liability yields a safety benefit; they do not generally recognize that market forces and regulation already encourage safety to a significant degree. Similarly, courts and commentators typically assume that the product liability system provides victims with desirable compensation, but they nearly always omit mention of the point that first-party insurance exists. Thus, they base their views of the benefits of product liability on simplistic assumptions and, as a consequence, radically overstate these benefits. At the same time, courts and commentators almost uniformly ignore the costs of the product liability system.

Because the policy basis that has been developed for product liability is so wanting, the burden required to question it cannot be said to be a substantial one. We believe that our arguments and evidence easily meet this burden. 